\title{
Alternative learning model in physics learning: Effect of the conceptual change model with cognitive conflict on critical thinking skill
}

\author{
Insih Wilujeng ${ }^{\mathrm{a} *}$, Zul Hidayatullah ${ }^{\mathrm{b}}$ \\ Universitas Negeri Yogyakarta. Jalan Colombo No 1, Yogyakarta, 55281, Indonesia \\ a insihuny@gmail.com; ${ }^{b}$ zulhidayatullah5@gmail.com \\ *Corresponding Author
}

Received: 17 January 2021; Revised: 9 May 2021; Accepted: 18 May 2021

\begin{abstract}
The purpose of this study was to apply the Conceptual Change Model (CCM) containing cognitive conflicts and to find out the difference in their effects on students' critical thinking skills. This type of research is a quasi-experimental study with an OnlyPosttest design. The sample in this study was 91 students at senior high school in Lombok, Indonesia. The sampling technique used in this research is simple random sampling. Students are divided into three sample groups: experiment class, control 1 class, and control 2. Critical thinking skills are measured based on five aspects: basic clarification, basic decisions, inference, evaluation, and further explanation. The test used to measure critical thinking skills is a description test. The material chosen is motion along a straight line. This research was tested by ANOVA 1 way. The test results show differences in the critical thinking skills of the three sample groups in the motion and straight line material. This shows that CCM containing cognitive conflict can be used as alternative learning to improve critical thinking skills. Subsequent research is carried out for different materials and different areas, but it should be noted that this learning is suitable for materials that experience many misconceptions.

Keywords: Conceptual Change Model; Cognitive Conflict; Critical Thinking Skills; Motion Along Straight Line.
\end{abstract}

How to Cite: Wilujeng, I., \& Hidayatullah, Z. (2021). Alternative learning model in physics learning: Effect of the conceptual change model with cognitive conflict on critical thinking skill. Momentum: Physics Joucation 111-120. https://doi.org/10.21067/mpej.v5i2.5260

\section{Introduction}

Students are not blank white sheets who are ready to accept anything when carrying out learning activities. Students already have preconceptions obtained from experience or previous learning, following constructivism theory that learners form their knowledge based on their experiences and prior knowledge. The substance of constructivist theory is that students find and modify knowledge and make it their own (Hidayatullah et al., 2018a). Research on learning has shown that learning physics often leaves conceptual errors because learning is unable to connect students' preconceptions with the new concepts being learned.

On the other hand, the impact of technological and scientific developments has made the focus of 21st-century learning emphasize higher-order thinking skills. There are several aspects: the demands and focus of 21st-century learning, commonly called 4C (critical thinking and problem solving, creativity and innovation, communication, \& collaboration). One of the expected skills in accordance with 21st-century learning is that students have critical thinking (Fitriani et al., 2019). Critical thinking skills are needed to obtain good problem solving (Walsh et al., 2019). 
Indonesia is one of the countries participating in developing critical thinking skills by including it in the 2013 curriculum as a skill that teachers and students must present. This is because students' critical thinking skills profile in Indonesia is included in the low category (Wulandari \& Nurhayati, 2018). Their critical thinking is low because they rarely practice those skills (Mundilarto \& Ismoyo, 2017). This fact causes the importance of teaching/training essential thinking and critical analysis skills because it has a positive impact on 21st-century learning (Fitriani et al., 2019). Critical thinking allows a person to assess statements, problems, provide facts, and consider various possibilities for making decisions (Danday \& Monterola, 2019). Students' cognitive and thinking skills also affect their critical thinking skills (Carvalho et al., 2015; Nurazizah et al., 2017). In measuring, there must be indicators that become benchmarks in assessing critical thinking skills, including indicators belonging to Ennis and Facione (Nisa et al., 2018; Santoso et al., 2018). Several indicators of critical thinking skills are basic clarification, basic decisions, inference, analysis, evaluation, reasoning, and providing further explanation. The results of this literature study are also in accordance with the results of observations and interviews at the school where the research was conducted. Based on the results of interviews and observations, it was found that learning was still limited to understanding the material and question exercises.

Based on these problems, the learning process must be focused on improving critical thinking skills. In learning, also requires knowledge of the ideas that already exist in students about the phenomena to be taught. Basically, students already have their own preconceptions, principles, and theoretical views. The learning process needs to be improved towards conceptual change so that students' thinking abilities can increase. The conceptual change model is one of the many learning models that can be used to produce meaningful learning. The use of CCM (Conceptual Change Model) allows students to exchange ideas through discussions and presentations because students can find out if their views are wrong and sometimes in contrast with scientific views. This often results in dissatisfaction with old views and triggers students to look for new ways that are acceptable, reasonable, and understandable (Tlala et al., 2014).

Learning with a conceptual change model will provide an understanding of the concepts found by experts, along with relevant examples and their implementations in everyday life. Conceptual change models lead to cognitive processes between initial conceptions and new concepts. The presence of new concepts with convincing evidence makes students feel satisfied, clear and understood so that students feel the benefits in life and overcome misconceptions. Conceptual change can occur when students experience a thought process and become aware of contradictions. Cognitive conflict is an effort to make students aware of contradictions to change students' conceptual (Hidayatullah et al., 2020). Learning with cognitive conflicts allows students to express initial conceptions and criticize concepts that are different from their conceptions, to change their conceptual (Akmam et al., 2018). Students are exposed to new situations through experimental/demonstration activities to solve problems in learning and form new concepts that are whole and more precise (Chow \& Treagust, 2013).

This study aims to apply a learning instruction-based conceptual change model that contains cognitive conflict on straight motion kinematics to promote students' critical thinking skills. The measured critical thinking skills are basic clarification, basic decisions, inference, evaluation, and further explanation. The novelty in this study is the addition of cognitive conflict content in the conceptual change model. It is used to train and improve critical thinking skills in accordance with the demands of 21st-century learning. This cognitive conflict is important to connect the initial concepts of students with the new concepts being learned. Learning theory Constructivists also say that to create balance in the structure cognitive of students, the process of assimilation is needed (Makhrus et al., 2014). Conceptual change models provide opportunities for students to construct new knowledge through assimilation and accommodation to achieve equilibration so that understanding the concept of students is more organized (Putra et al., 2014). This research was conducted with online learning due to the Covid-19 pandemic, which demands distance learning. 


\section{Method}

This study is a quasi-experimental study with an Only-Posttest design (Table 1). The sample in this study was 91 students of Senior High School in Lombok, West Nusa Tenggara, Indonesia. The sampling technique used in this research is simple random sampling. The sample was divided into three classes: the experimental and control 1 class and the control 2 class.

Table 1. Research Design

\begin{tabular}{cccc}
\hline No. & Class & Treatment & Posttest \\
\hline 1. & Experiment & $\mathrm{X}_{1}$ & $\mathrm{O}_{1}$ \\
2. & Control 1 & $\mathrm{X}_{2}$ & $\mathrm{O}_{2}$ \\
3. & Control 2 & $\mathrm{X}_{3}$ & $\mathrm{O}_{3}$ \\
\hline
\end{tabular}

The experimental class $\left(\mathrm{X}_{1}\right)$ is a student in the experimental class who gets learning with $\mathrm{CCM}$ containing cognitive conflict; the control 1 class $\left(X_{2}\right)$ is a student in the control class who gets learning with problem-based learning. The control 2 class $\left(X_{3}\right)$ is a student in the control class with conventional learning. $\mathrm{O}_{1}$ is a posttest in the experimental class, $\mathrm{O}_{2}$ is a posttest in the control 1 class, and $\mathrm{O}_{3}$ is a posttest in the control 2 class. This research was conducted in 3 learning meetings and one posttest. The material used is motion along a straight line. This research was conducted during online learning due to the Covid-19 pandemic. The instrument used to measure critical thinking is a description test of 5 items. Hypothesis testing in this study used Anova one-way, and the prerequisite test used the Levene test for homogeneity and the Shapiro-Wilk test for normality.

\section{Results and Discussion}

Result

Learning is carried out in the three sample group classes with three online meetings via WhatsApp Group and Quipper's LMS (Learning Management System). Each class is given a different learning treatment which can be seen based on the learning instructions used (student worksheet). In the experimental class, the implementation of learning using CCM based student worksheets contains cognitive conflicts. Whereas in control class 1 using learning assisted by student worksheets. Meanwhile, control class 2 only uses conventional learning. Before carrying out learning activities, researchers designed the learning instructions to be used. The characteristics of CCM learning containing cognitive conflicts are visible in the part of the student worksheets that are arranged according to the CCM syntax containing cognitive conflicts. The form and structure of student worksheets can be observed in Figure 1 to Figure 4.

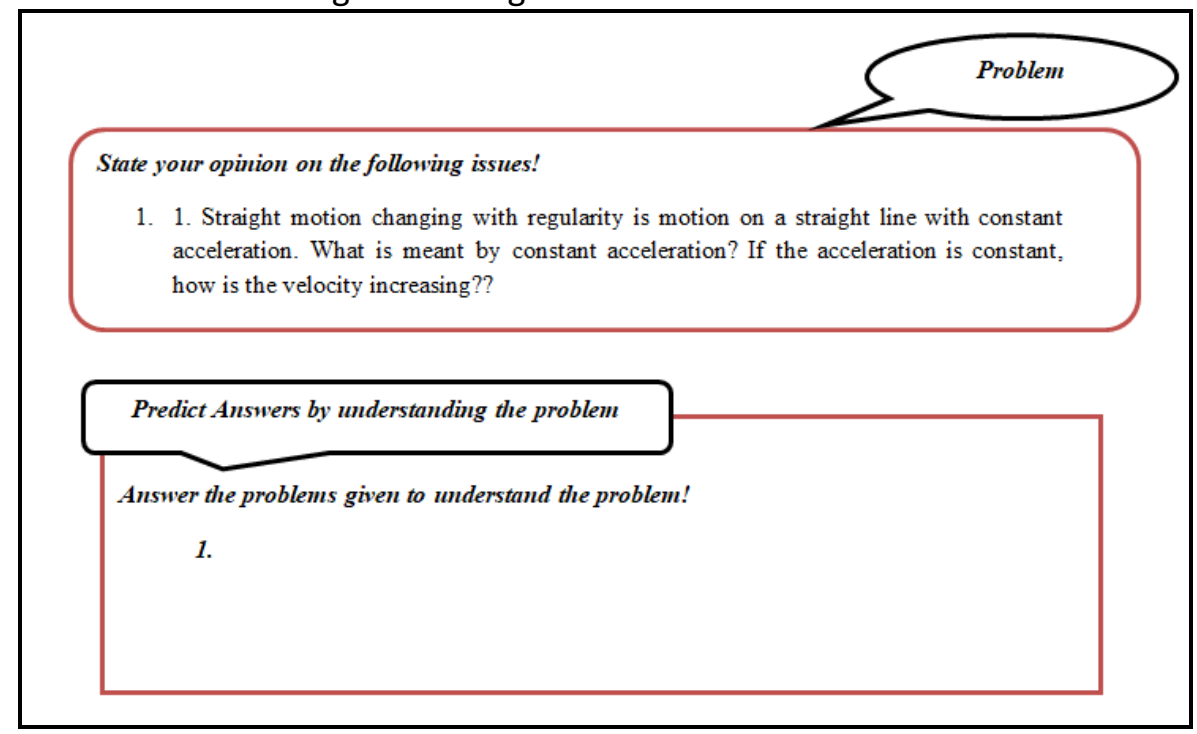

Figure 1. The first part of the Student Worksheet 
Cognitive conflicts in CCM learning can be raised if educators know students' preconceptions so that educators can design simulation/experimental activities that conflict with students' preconceptions. Therefore, the first part of the student worksheet must contain problem-giving activities and predict student answers to the problem. This is one way to detect students' preconceptions; another way is to administer diagnostic tests. The second and third activities on the student worksheets contain experimental activities (Figure 2) to prove students' predictions from the first activity.

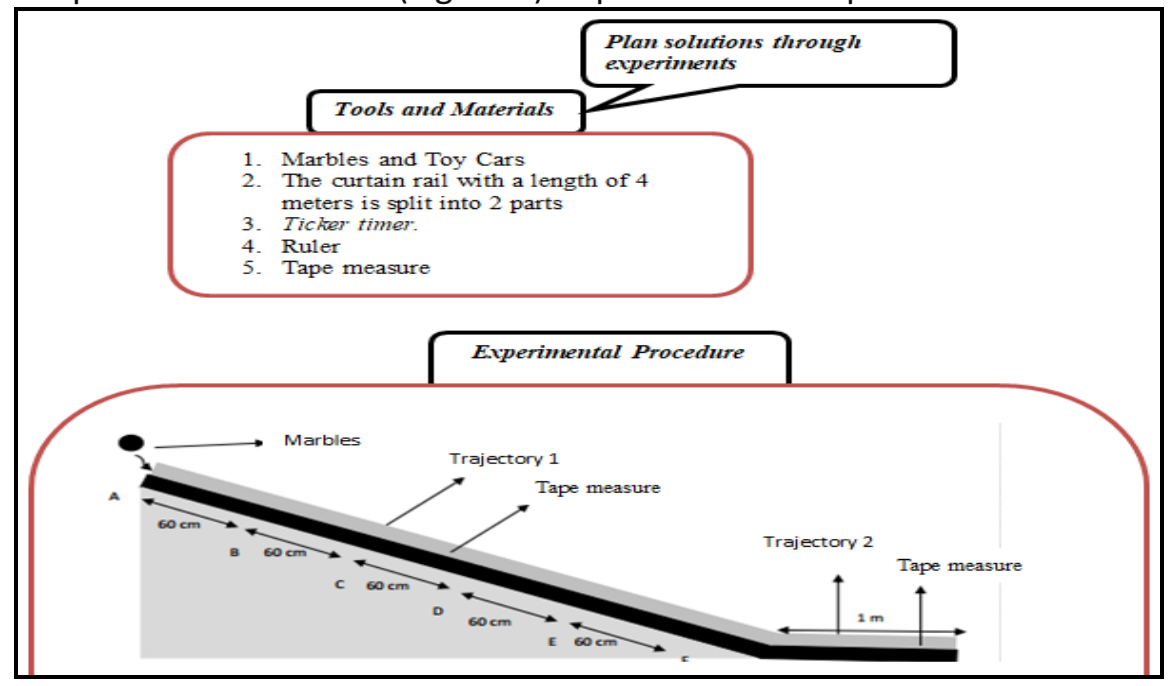

Figure 2. The second part of the Student Worksheet

Furthermore, the third part of the student worksheet contains the results of the experiment and the problems that must be solved based on the experiment (Figure 3). This aims to bring up cognitive conflict in students. This activity can also make students experience a process of assimilation and accommodation for the formation of appropriate new concepts.

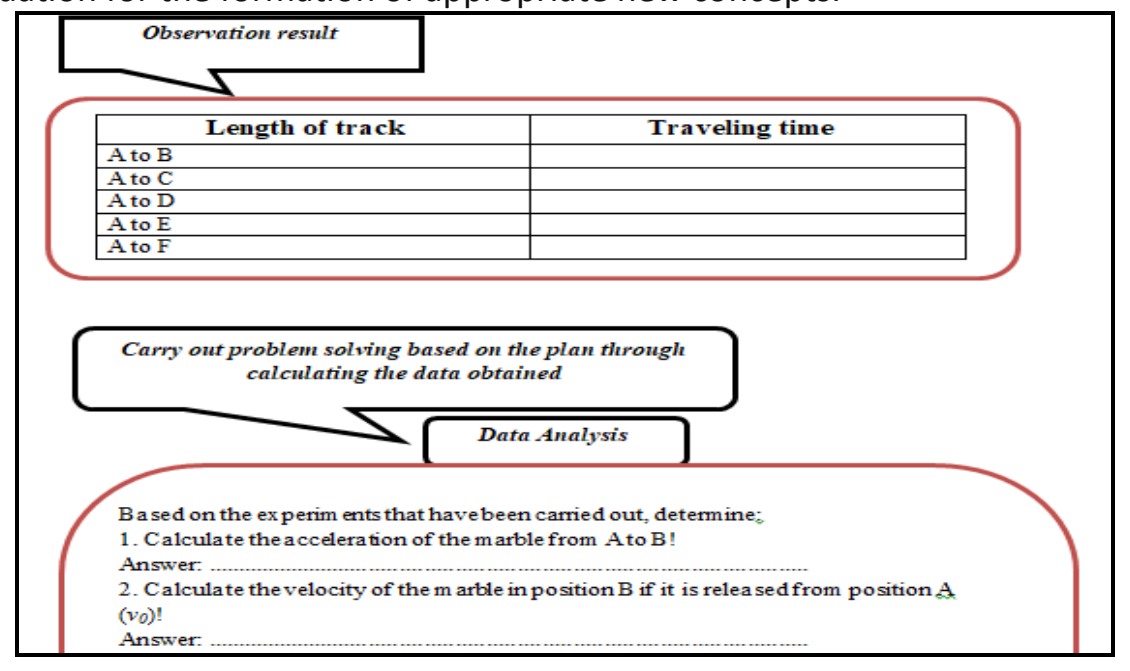

Figure 3. The third part of the Student Worksheet

The final section of the student worksheet contains questions that fit the material and examples in real life and conclusions related to the material being studied (Figure 4). The aim is to reconstruct students' ideas so that the concept is stronger and more precise. This relates to connecting students' preconceptions with scientific concepts that are proven in experiments/simulations.

This student worksheet is applied during three learning meetings for motion along with straight-line material. After learning, students are given a final test to determine their critical thinking skills after learning with CCM contains cognitive conflicts. The final test results of students in the three groups can be seen in Figure 5. This final test aims to determine the differences in students' critical thinking skills in 3 different classes who are given different learning. The test instrument used was a description test with five indicators of critical thinking. The critical thinking skills in terms of the 
lowest, highest and average scores for the experimental class group who studied with CCM contains cognitive conflicts is higher than the other two sample groups

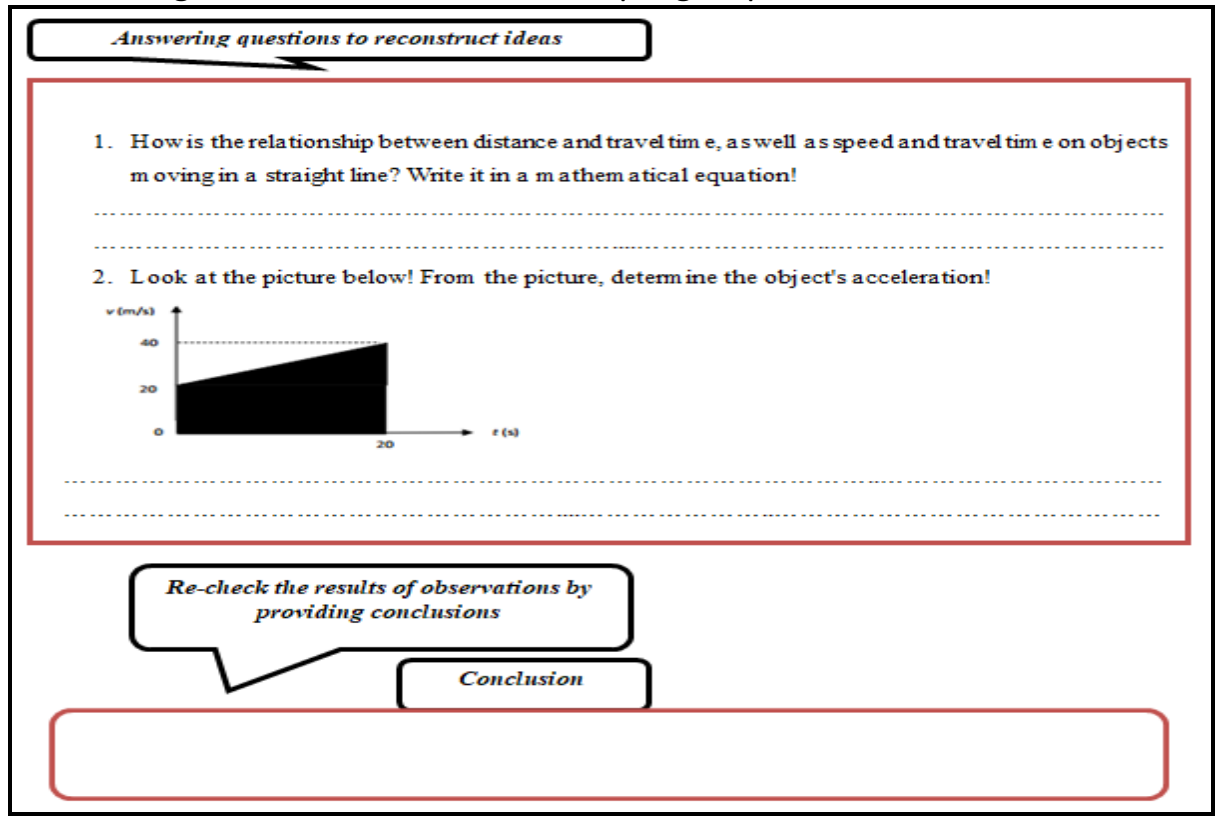

Figure 4. End of Student Worksheet

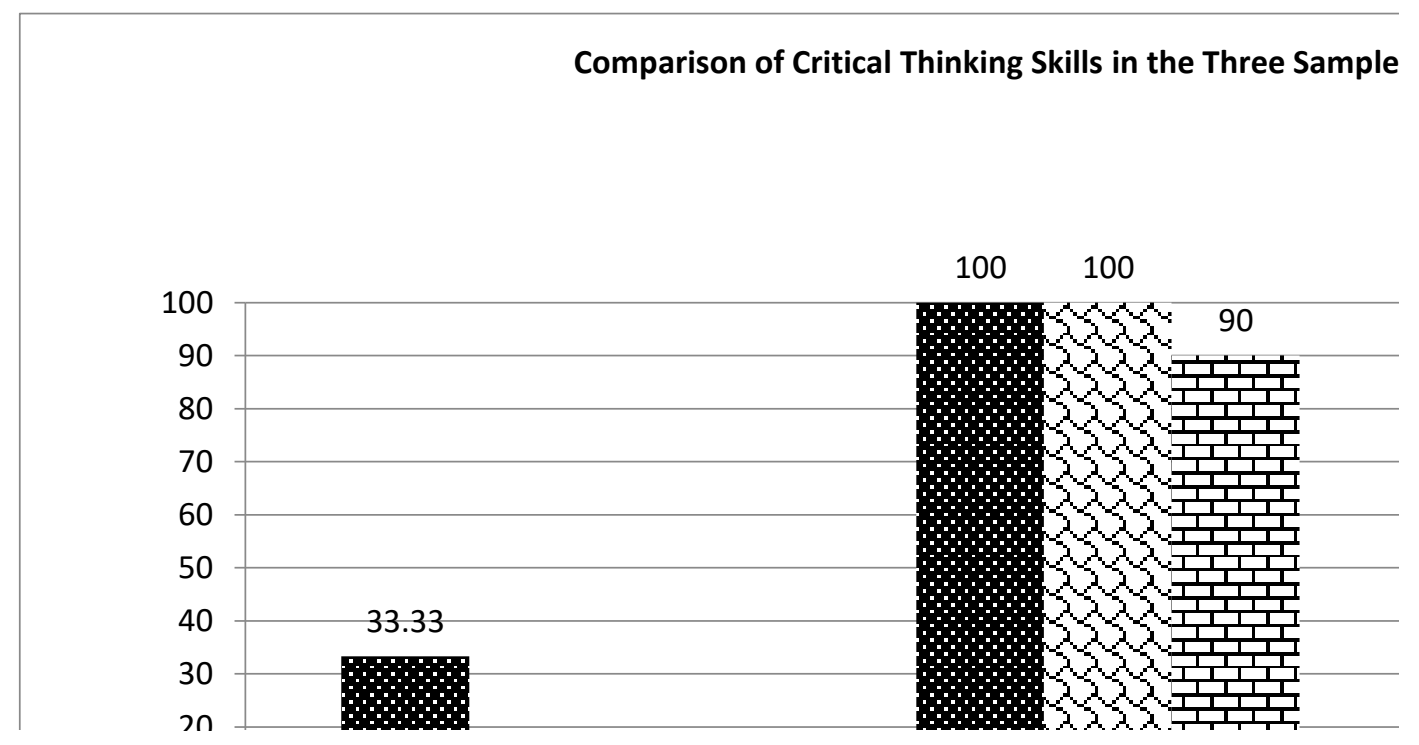

Figure 5. Comparison of Critical Thinking Skills Scores in the Three Sample Groups

Based on the results of the final Test in Figure 5, it is found that the lowest score in the experimental class who learns with CCM contains cognitive conflict is 33.33 . Whereas in control class 1 and control class 2, the lowest scores were 0 and 3.33, respectively. The highest score in the experimental class was 100, control class 1 was 100, and control class 2 was 90 . The most significant difference was seen from the average score of each class, where the experimental class had the highest average of 68.99. Students' critical thinking skill in this experimental class is higher because basically, CCM learning contains cognitive conflict is able to reconstruct students' ideas and train their thinking skills. Students also prove wrong preconceptions through direct experiments that they experience. Furthermore, ANOVA one-way test was carried out to see the difference in the results of critical thinking skills, which differed significantly or not. The prerequisite test for ANOVA one-way is the normality test with Shapiro-Wilk and homogeneity test with Levene's test. This prerequisite test is conducted based on posttest data on critical thinking skills. The prerequisite test results are shown in Table 2. 
Momentum: Physics Education Journal, 5 (2), 2021, 116

Insih Wilujeng, Zul Hidayatullah

Table 2. ANOVA one-way Prerequisite Test Results

\begin{tabular}{|c|c|c|c|c|}
\hline \multirow[b]{2}{*}{ No. } & \multirow[b]{2}{*}{ Class Type } & \multirow[b]{2}{*}{ Data Source } & \multicolumn{2}{|c|}{ Significance of the Prerequisite Test } \\
\hline & & & $\begin{array}{l}\text { Homogeneity } \\
\text { Test Levene's }\end{array}$ & $\begin{array}{c}\text { Normality } \\
\text { Test Shapiro-Wilk }\end{array}$ \\
\hline 1. & Experimental Class & & & 0.336 \\
\hline 2. & Control 1 Class & Posttest Critical Thinking & 0.300 & 0.776 \\
\hline 3. & Control 2 Class & & & 0.071 \\
\hline
\end{tabular}

The prerequisite test results show that the significance value of the homogeneity and normality test is greater than 0.05 . This shows that the three sample groups are normally distributed and homogeneous. Based on these results, the ANOVA one-way test can be continued to determine the difference in the effect of the learning group using CCM, which contains cognitive conflict with the group learning using other models. The results of the ANOVA one-way test are presented in Table 3.

Table 3. Result ANOVA one-way test

\begin{tabular}{lccccc}
\hline \multicolumn{5}{c}{ ANOVA } \\
Critical Thinking Skills \\
\hline Sum of Squares & df & Mean Square & F & Sig. \\
\hline Between Groups & 2960.120 & 2 & 1480.060 & 3.579 & 0.032 \\
Within Groups & 36394.559 & 88 & 413.575 & & \\
Total & 39354.679 & 90 & & & \\
\hline
\end{tabular}

Based on the results in Table 3, the ANOVA one-way test significance value is 0.032 . When the test significance is less than 0.05 , it indicates that there is a difference in the effect of critical thinking skills in the three sample groups. To determine the different groups, a posthoc follow-up test was performed (Table 4). The Scheffe test carried out the posthoc test on this data.

Table 4. Posthoc Test

\begin{tabular}{lllcc}
\hline \multicolumn{5}{c}{ Posthoc } \\
\hline Test Type & \multicolumn{1}{c}{ (I) Class Type } & \multicolumn{1}{c}{ (J) Class Type } & Mean Difference (I-J) & \multicolumn{1}{c}{ Sig. } \\
\hline \multirow{5}{*}{ Scheffe } & \multirow{2}{*}{ X MIPA 4 (Control 1) } & X MIPA 5 (Experiment) & -9.019 & 0.214 \\
\cline { 3 - 5 } & \multirow{2}{*}{ X MIPA 5 (Experiment) } & X MIPA 6 (Control 2) & 4.569 & 0.700 \\
\cline { 2 - 5 } & \multirow{2}{*}{ X MIPA 6 (Control 2) } & X MIPA 4 (Control 1) & 9.019 & 0.214 \\
& & X MIPA 4 (Control 2) & 13.588 & 0.039 \\
\hline
\end{tabular}

Based on the Scheffe test in Table 4, it is known that a significant difference occurred in the experimental class who studied with CCM contains cognitive conflict with the control 2 class who studied conventionally (Sig. $<0.05$ ). This shows that learning with CCM contains cognitive conflict that has a better effect on critical thinking skills in motion and straight-line material compared to conventional learning. Meanwhile, if it is compared to the control 2 class who learns with problem-based learning, the difference is not significant. This is because each learning model has its own characteristics and advantages.

\section{Discussions}

CCM learning containing cognitive conflicts was conducted three times in learning with an online system due to the Covid-19 pandemic where the Indonesian government made a policy of learning from home (online learning). The platforms used in learning are Whatsapp Group and Quipper. Educators create 24 Whatsapp groups, and each group contains 4-5 students. During the learning process in the Whatsapp group for the experimental class, educators always give some perceptual questions to attract students' attention and provide simulations/simple descriptions of the material to be studied. After that, educators give student worksheets and ask students to discuss and work on them. This activity was repeated until the third meeting. After that, the posttest was carried out by giving five items of the critical thinking test. This critical thinking test is prepared based 
on five aspects of critical thinking, namely basic explanation, basic decisions, inference, evaluation, and further explanation. In the experimental class, the implementation of learning uses CCM and CCM-based worksheets, which contain cognitive conflicts, while in the control class 1 uses learning assisted by student worksheets. Meanwhile, control class 2 only uses conventional learning.

The first meeting was related to ordinary straight motion material, where based on the analysis of students' predictions about a problem, students still misunderstood the concepts of distance and displacement. Likewise, the second and third meetings related to the matter of straight motion, which changes regularly and free-fall motion. Students still experience errors in some of their concepts at this stage, but after experiencing learning with CCM, which is full of cognitive conflicts, students understand the correct concepts. Students' critical thinking skills in the experimental class were better than students in other classes. This can be seen based on the results of the critical thinking posttest.

Based on the posttest results, it can be seen that the experimental class has a better score than the control class when viewed from the lowest, highest, and average scores. Learning with this conflict-ridden cognitive CCM allows students to express their prejudices and prove them through experimental activities. There is a cognitive conflict process through assimilation and accommodation, the formation of new conceptions that are appropriate and following scientific concepts. This will improve students' understanding of concepts and practice their thinking skills, including critical thinking skills. CCM in the learning process presents a cognitive process, namely the initial conception of students that contradicts the new concept conveyed by the teacher so that the new concept is believed to be true by students. CCM is a learning model that describes the interaction between existing conceptions (preconceptions) and new concepts (Handayani et al., 2014). The most important thing from cognitive conflict through problem giving and answer prediction is an important point in the application of CCM. This way, educators can find out the right experimental solutions to change the wrong conceptions of students. The most important thing in the cognitive conflict process is to draw attention to the contradiction (Kang et al., 2010). After proving prejudice through experiments conducted, students are allowed to work on several questions to apply and reconstruct these preconceptions to correct scientific concepts. Learning with a conceptual change model will provide an understanding of concepts according to the findings of experts accompanied by examples and relevant applications in everyday life. Conceptual change models lead to cognitive processes between initial conceptions and new concepts. The presence of new concepts with convincing evidence makes students feel satisfied, clear and understood to feel the benefits and overcome misconceptions. Conceptual change can occur when students experience a thought process and become aware of contradictory states. Learning with cognitive conflict is an effort to make students aware of contradictions to change students' concepts (Hidayatullah et al., 2018b). Contradictory states of cognitive conflict play an important role in students' conceptual change (Kang et al., 2010). Cognitive conflict occurs when students experience a mismatch or incompatibility in cognition due to anomalous states between experiences and scientific concepts (Madu \& Orji, 2015).

Learning with CCM contains cognitive conflicts that give freedom to students in learning. Educators function as facilitators and mediators to connect students' preconceptions with the new concepts being learned. When students' prejudices are wrong, the experimental activities carried out will help correct their preconceptions. When students' preconceptions are correct, experimental activities are used to help reinforce the concept. The conceptual change model is a model of learning that can change students who are not suitable or mistaken into correct concepts according to scientific concepts. This will improve their critical thinking skills because they are continuously trained to improve their thinking skills (Danday \& Monterola, 2019). The conceptual change model can help learners develop critical thinking because this model familiarizes students to analyze problems and solve them (Rizaldi et al., 2019). Conceptual change model with the cognitive conflict approaches can improve the critical thinking skills of participant's students. This is because, during the learning process, students are accustomed to criticizing opposite concepts. The learning process is directed at the confrontation of conceptions through experiments and fundamental questions that are different from students' concepts (Makhrus et al., 2020). This opinion is by the research results, where stu- 
dents in the experimental class experienced increased critical thinking skills. CCM learning with cognitive conflict is suitable for material that has many misconceptions, but it should be noted that this learning requires a lot of preparation to create a cognitive conflict situation. According to Posner's conceptual changes, this cognitive conflict-laden CCM learning provides students with the opportunity to experience four thinking conditions. These conditions are (1) dissatisfaction with existing conceptions (dissatisfaction); (2) Understand a new concept (intelligible); (3) the new conception must be acceptable and consistent with the standard of knowledge (plausible); (4) new conceptions should be able to help to solve problems (fruitful) (Chen \& Wang, 2016; Nadelson et al., 2018).

Basically, there is no perfect learning model. Each learning model has advantages and disadvantages. CCM learning is loaded with cognitive conflict, which is more suitable for physics material that has many misconceptions. Online learning that is applied is also not able to optimally facilitate CCM learning activities containing cognitive conflicts. Educators and students in their learning experience many obstacles. However, despite all these obstacles, it can be concluded that CCM learning contains cognitive conflict that can be used as alternative learning to train and even improve students' critical thinking skills. This is because learning with CCM that contains cognitive conflicts better affects critical thinking skills in motion along with straight-line material compared to conventional learning.

\section{Conclusion}

There are differences in students' critical thinking skills in the three classes used as research samples. This difference occurs in students who learn in the experimental class (CCM contains cognitive conflict) with students in the control 2 class (conventional learning). Meanwhile, students in the experimental class with the control 1 class (problem-based learning) have the same critical thinking skills. This is because each learning model has its own advantages in improving critical thinking skills. However, it should be noted that CCM contains cognitive conflict that requires careful preparation to reach a state of contradiction and the lessons suitable for this model are lessons that are subject to many misconceptions.

\section{References}

Akmam, A., Anshari, R., Amir, H., Jalinus, N., \& Amran, A. (2018). Influence of learning strategy of cognitive conflict on student misconception in computational physics course. IOP Conference Series: Materials Science and Engineering, 335(1), 012074. https://doi.org/10.1088/1757899X/335/1/012074

Carvalho, C., Fíuza, E., Conboy, J., Fonseca, J., Santos, J., Gama, A. P., \& Salema, M. H. (2015). Critical thinking, real life problems and feedback in the sciences classroom. Journal of Turkish Science Education, 12(2), 21-31. https://doi.org/10.12973/tused.10138a

Chen, Y. T., \& Wang, J. H. (2016). Analyzing with Posner's conceptual change model and Toulmin's model of argumentative demonstration in senior high school students' mathematic learning. International Journal of Information and Education Technology, 6(6), 457-464. https://doi.org/10.7763/IJIET.2016.V6.732

Chow, T.-C. F., \& Treagust, D. F. (2013). An intervention study using cognitive conflict to foster conceptual change. Journal of Science and Mathematics Education in Southeast Asia, 36(1), 44-64. http://hdl.handle.net/20.500.11937/42636

Danday, B. A., \& Monterola, S. L. C. (2019). Effects of microteaching multiple-representation physics lesson study on pre-service teachers' critical thinking. Journal of Baltic Science Education, 18(5), 692-707. https://doi.org/10.33225/jbse/19.18.692

Fitriani, H., Asy'ari, M., Zubaidah, S., \& Mahanal, S. (2019). Exploring the prospective teachers' critical thinking and critical analysis skills. Jurnal Pendidikan IPA Indonesia, 8(3), 379-390. https://doi.org/10.15294/jpii.v8i3.19434 
Handayani, N. K. N., Redhana, I. W., \& Kartowarsono, N. (2014). The model of conceptual change in learning chemistry. E-Journal Kimia Visvitalis Pendidikan Ganesha, 2(1), 56-65. https://doi.org/10.23887/jjpk.v1i2.3973

Hidayatullah, Z., Jumadi, J., Nadhiroh, N., Kartika, E., Nuha, A. A., \& Erlangga, S. Y. (2020). Identifikasi miskonsepsi dan konflik kognitif fisika: kasus terkait perubahan konseptual. EDUSAINS, 12(1), 64-71. https://doi.org/10.15408/es.v12i1.13504

Hidayatullah, Z., Makhrus, M., \& Gunada, I. W. (2018a). Analisis tingkat kemampuan berpikir kritis gelombang mekanik melalui pembelajaran dengan pendekatan konflik kognitif. Jurnal Pendidikan Fisika Dan Teknologi, 4(2), 151. https://doi.org/10.29303/jpft.v4i2.565

Hidayatullah, Z., Makhrus, M., \& Gunada, I. W. (2018b). Identifikasi tingkat konflik kognitif materi gelombang mekanik melalui pembelajaran dengan pendekatan konflik kognitif. KONSTAN JURNAL FISIKA DAN PENDIDIKAN FISIKA, 3(2), 66-73. https://doi.org/10.20414/konstan.v3i2.10

Kang, H., Scharmann, L. C., Kang, S., \& Noh, T. (2010). Cognitive conflict and situational interest as factors influencing conceptual change. International Journal of Environmental and Science Education, 5(4), 383-405. http://www.ijese.net/makale/1424.html

Madu, B. C., \& Orji, E. (2015). Effects of cognitive conflict instructional strategy on students' conceptual change in temperature and heat. SAGE Open, 5(3), 215824401559466. https://doi.org/10.1177/2158244015594662

Makhrus, M., Ayub, S., Wahyudi, W., Verawati, N., \& Busyairi, A. (2020). Kemampuan berpikir kritis mahasiswa pada materi optik saat proses pembelajaran dengan CCM-CCA berbantuan eksperimen virtual. Kappa Journal, 4(2), 143-148. https://doi.org/10.29408/kpj.v4i2.2632

Makhrus, M., Nur, M., \& Widodo, W. (2014). Model perubahan konseptual dengan pendekatan konflik kognitif (MPK-PKK). JURNAL PIJAR MIPA, 9(1), 20-25. https://doi.org/10.29303/jpm.v9i1.39

Mundilarto, M., \& Ismoyo, H. (2017). Effect of problem-based learning on improvement physics achievement and critical thinking of senior high school student. Journal of Baltic Science Education, 16(5), 761-779. http://www.scientiasocialis.lt/jbse/?q=node/609

Nadelson, L. S., Heddy, B. C., Jones, S., Taasoobshirazi, G., \& Johnson, M. (2018). Conceptual change in science teaching and learning: Introducing the dynamic model of conceptual change. International Journal of Educational Psychology, 7(2), 151-195. https://doi.org/10.17583/ijep.2018.3349

Nisa, E. K., Jatmiko, B., \& Koestiari, T. (2018). Development of guided inquiry-based physics teaching materials to increase critical thinking skills of highschool students. Jurnal Pendidikan Fisika Indonesia, 14(1), 18-25. https://doi.org/10.15294/jpfi.v14i1.9549

Nurazizah, S., Sinaga, P., \& Jauhari, A. (2017). Profil kemampuan kognitif dan keterampilan berpikir kritis siswa SMA pada materi usaha dan energi. Jurnal Penelitian \& Pengembangan Pendidikan Fisika, 3(2), 197-202. https://doi.org/10.21009/1.03211

Putra, I. W. E., Sadia, I. W., \& Suastra, I. W. (2014). Pengaruh model pembelajaran perubahan konseptual terhadap pemahaman konsep siswa ditinjau dari gaya kognitif. Journal of Physics $A$ : Mathematical and Theoretical, 4(2), 191-202. https://ejournalpasca.undiksha.ac.id/index.php/jurnal_ipa/article/view/1058

Rizaldi, D. R., Makhrus, M., \& Doyan, A. (2019). Analisis tingkat kemampuan berpikir kritis dengan model perubahan konseptual ditinjau dari gaya belajar siswa. Jurnal Pendidikan Fisika Dan Teknologi, 5(1), 74. https://doi.org/10.29303/jpft.v5i1.794

Santoso, T., Yuanita, L., \& Erman, E. (2018). The role of student's critical asking question in developing student's critical thinking skills. Journal of Physics: Conference Series, 953(1). https://doi.org/10.1088/1742-6596/953/1/012042 
Tlala, B., Kibirige, I., \& Osodo, J. (2014). Investigating grade 10 learners' achievements in photosynthesis using conceptual change model. Journal of Baltic Science Education, 13(2), 155-164.

Walsh, C., Quinn, K. N., Wieman, C., \& Holmes, N. G. (2019). Quantifying critical thinking: Development and validation of the physics lab inventory of critical thinking. Physical Review Physics Education Research, 15(1), 010135. https://doi.org/10.1103/PhysRevPhysEducRes.15.010135

Wulandari, A. Y. R., \& Nurhayati, N. (2018). The relationship between verbal ability and critical thinking skill: The implementation of susan loucks horsley model. Jurnal Ilmiah Pendidikan Fisika Al-Biruni, 7(1), 89-97. https://doi.org/10.24042/jipfalbiruni.v7i1.2507 